\title{
Bounds for the Number of Generators of a Finite Group
}

\author{
Morris Newman
}

\author{
Institute for Basic Standards, National Bureau of Standards, Washington, D.C. 20234
}

(October 3, 1967)

\begin{abstract}
It is proved that if $G$ is a finite group of order $n$, then the generator rank of $G$ does not exceed the total number of primes dividing $n$ and is equal to this number for infinitely many groups $G$.
\end{abstract}

Key Words: Bounds, elementary abelian groups, generator rank, Sylow subgroups.

Let $G$ be a finite group of order $n$. By the generator rank of $G$ (denoted by $r(G)$ ) we shall mean the smallest number of elements of $G$ which generate $G$. In this note we shall give bounds for $r(G)$ in terms of the group order $n$, and also some relevant facts about $p$-groups.

Let the canonical decomposition of $n$ into its prime power factors be

$$
n=p_{1}^{e_{1}} p_{2}^{e_{2}} \ldots p_{s}^{e_{s}}
$$

and define

$$
\Omega(n)=\sum_{i=1}^{s} e_{i},
$$

so that $\Omega(n)$ is the total number of primes dividing $n$. Let $G_{i}$ be any Sylow subgroup of $G$ of order $p_{i}^{e_{i}}$, and suppose that $C_{i}$ is a cyclic group of largest order $p_{i}^{f i}$ contained in $G_{i}, 1 \leqslant i \leqslant s$. Then we shall prove

THEOREM 1. The function $\mathrm{r}(\mathrm{G})$ satisfies

$$
r(G) \leqslant \sum_{i=1}^{s}\left(e_{i}-f_{i}+1\right)
$$

If $\mathrm{G}$ is the elementary abelian group of order $\mathrm{p}^{\mathrm{e}}$ (p prime), then (1) becomes an equality.

A corollary of Theorem 1 is

COROLlaRY 1. The function $\mathrm{r}(\mathrm{G})$ satisfies

$$
r(G) \leqslant \Omega(n) .
$$

If $\mathrm{G}$ contains an element of prime power order $\mathrm{p}^{\mathrm{f}}$ with $\mathrm{f}>1$, then the inequality (2) is strict.

We note first that if $N$ is a normal subgroup of $G$, then

$$
r(G) \leqslant r(G / N)+r(N)
$$

and if $G=\left\{H_{1}, H_{2}, \ldots, H_{t}\right\}$ (the group generated by the subgroups $H_{1}, H_{2}, \ldots, H_{t}$ of $G$ ) then

$$
r(G) \leqslant \sum_{i=1}^{t} r\left(H_{i}\right) .
$$

We first prove

LEMMA 1. We have

$$
\mathrm{G}=\left\{\mathrm{G}_{1}, \mathrm{G}_{2}, \ldots, \mathrm{G}_{\mathrm{s}}\right\},
$$

where $\mathrm{G}_{\mathrm{i}}$ is any Sylow subgroup of $\mathrm{G}$ of order $\mathrm{p}_{\mathrm{i}}^{\mathrm{e}_{\mathrm{i}}}$, $1 \leqslant \mathrm{i} \leqslant \mathrm{s}$.

Proof. Put

$$
H=\left\{G_{1}, G_{2}, \ldots, G_{s}\right\}, \quad o(H)=m .
$$

Since $H \supset G_{i}, m$ must be divisible by $p_{i}^{e_{i}}, 1 \leqslant i \leqslant s$. Since these are pairwise relatively prime, $m$ must be divisible by their product. Hence $m$ is divisible by $n$, which implies that $m=n, H=G$. This completes the proof.

Lemma 1 and (4) imply that

$$
r(G) \leqslant \sum_{i=1}^{s} r\left(G_{i}\right) .
$$

We now prove LEMMA 2. We have

$$
\mathrm{r}\left(\mathrm{G}_{\mathrm{i}}\right) \leqslant \mathrm{e}_{\mathrm{i}}-\mathrm{f}_{\mathrm{i}}+1, \quad \mathrm{l} \leqslant \mathrm{i} \leqslant \mathrm{s},
$$

where $\mathrm{C}_{\mathrm{i}}$ is a cyclic group of largest order $\mathrm{p}_{\mathrm{i}}^{\mathrm{f}_{\mathrm{i}}}$ contained in $\mathrm{G}_{\mathrm{i}}$.

Proof. By one the Sylow theorems there is a chain of groups 


$$
G_{i} \supset H_{1} \supset H_{2} \supset \ldots . \supset H_{e_{i}-f_{i}-1} \supset C_{i},
$$

where $H_{k}$ is of order $p_{i}^{e_{i}-k}\left(1 \leqslant k \leqslant e_{i}-f_{i}-1\right)$, and each member of the chain is a normal subgroup of the one preceding it. Using (3) and noting that all the quotient groups in (8) are cyclic of order $p_{i}$, we find in succession that

$$
\begin{aligned}
r\left(G_{i}\right) & \leqslant 1+r\left(H_{1}\right) \\
& \leqslant 2+r\left(H_{2}\right) \\
& . \\
& \leqslant e_{i}-f_{i}-1+r\left(H_{e_{i}-f_{i}-1}\right) \\
& \leqslant e_{i}-f_{i}+r\left(C_{i}\right) \\
& =e_{i}-f_{i}+1 .
\end{aligned}
$$

This completes the proof.

The first part of Theorem 1 now follows from Lemmas 1 and 2. The second part of Theorem 1 is clear, and Corollary 1 is an immediate consequence of Theorem 1.

We note that the weaker inequality

$$
r(G) \leqslant \log n / \log 2
$$

is immediate. For if $g_{1}, g_{2}, \ldots . . g_{r}(r=r(G))$ are generators of $G$, then the $2^{r}$ elements

$$
g_{1^{1}}^{\epsilon^{1}} g_{2^{2}}^{\epsilon} \cdots g_{r^{r}}^{\epsilon}
$$

where each exponent is either 0 or 1 , are distinct.

Notice that Corollary 1 implies that if $G$ is of prime power order $p^{e}$, then

$$
r(G) \leqslant e,
$$

and the inequality (9) is strict unless every element of $G$ is of order $p$.

On the other hand, if every element of $G$ is of order $p$ it does not necessarily mean that $r(G)=e$. For example the Burnside group

$$
B(3,2)=F_{2} / F_{2}^{3},
$$

where $F_{2}$ is the free group on 2 generators and $F_{2}^{3}$ the fully invariant subgroup generated by the cubes of the elements of $F_{2}$, is known to have order $3^{3}$ (see $[1],{ }^{1}$ p. 324). Thus $B(3,2)$ is of generator rank 2 , every element of $B(3,2)$ is of order 3 , but the order of $B(3,2)$ is not $3^{2}$.

\footnotetext{
'Marshall Hall, Jr., The Theory of Groups (Macmillan, New York, 1959).
}

As was previously noted, the elementary abelian group of order $p^{e}$ makes (9) an equality. In this connection we prove

THEOREM 2. The only groups of prime power order $\mathrm{p}^{\mathrm{e}}$ and generator rank e are the elementary abelian ones. Proof. We proceed by induction on the exponent $e$. The result is certainly correct for $e=1$ and $e=2$. Assume the result correct for all exponents $<e$, and let $G$ be any group of order $p^{e}$ and generator rank $e$. As was previously noted, every element of $G$ is of order $p$. Let $g_{1}, g_{2}, \ldots, g_{e}$ be a basis for $G$;

$$
G=\left\{g_{1}, g_{2}, \ldots, g_{e}\right\} .
$$

Then every element of $G$ occurs precisely once among the $p^{e}$ elements

$$
g_{1}^{r_{1}} g_{2}^{r_{2}} \ldots g_{e}^{r_{e}}, \quad 0 \leqslant r_{i} \leqslant p-1, \quad 1 \leqslant i \leqslant e .
$$

For if two such elements are equal, say

$$
g_{1}^{r_{1}} g_{2}^{r_{2}} \ldots g_{e}^{r_{e}}=g_{1}^{s} g_{2}^{s_{2}} \ldots g_{e}^{s} e,
$$

then

$$
g_{1}^{r_{1}-s_{1}} \boldsymbol{\epsilon}\left\{g_{2}, g_{3}, \ldots, g_{e}\right\}
$$

which is impossible unless $r_{1}=s_{1}$, since otherwise $\left(r_{1}-s_{1}, p\right)=1$ and it would follow that

$$
g_{1} \in\left\{g_{2}, g_{3}, \ldots, g_{e}\right\} .
$$

Repeating the argument we find in succession that $r_{2}=s_{2}, \ldots ., r_{e}=s_{e}$.

Now let $G_{i}$ be the subgroup of $G$ generated by $g_{1}$, $g_{2}, \ldots, g_{i-1}, g_{i+1}, \ldots ., g_{e}(1 \leqslant i \leqslant e)$. Then the previous argument shows that $o\left(G_{i}\right)=p^{e-1}$, and furthermore $r\left(G_{i}\right)=e-1$. By the induction hypothesis, $G_{i}$ is elementary abelian $(1 \leqslant i \leqslant e)$. This certainly implies that $G$ is abelian, since $e>2$. But the only abelian group of order $p^{e}$ in which every element is of order $p$ is the elementary abelian group of that order. Hence the result follows for the exponent $e$, and the proof is concluded.

It is of course perfectly possible for $r(G)$ to remain bounded as $o(G)$ goes to infinity. For example the symmetric group $S_{m}(m \geqslant 3)$, and any metacyclic group have generator rank 2 . 


\section{Publications of the National Bureau of Standards*}

\section{Selected Abstracts}

Classification of normal subgroups of the modular group, M. Newman, Trans. Am. Math. Soc. 126, No.2, 267-277 (Feb. 1967). The normal subgroups of the classical modular group are studied, and theorems such as the following are proved:

(1) There are no normal subgroups of index $12 q$, where $q$ is a prime $>11$.

(2) There are exactly $1+\left(\frac{q}{3}\right)$ normal subgroups of index $6 q$, where $q$ is a prime $>3$ and $\left(\frac{q}{3}\right)$ is the Legendre symbol.

(3) If there is no normal subgroup of index $\mu$ and $q$ is a prime $>\mu$, then there is no normal subgroup of index $q^{k} \mu$ for all $k \geqslant 0$.

Key Words: Modular group, normal subgroups, congruence groups, parabolic classes.

Note on normal subgroups of the modular group, L. Greenberg, Proc. Am. Math. Soc. 17, No. 5 1195-1198 (Oct. 1966).

Let $N$ be a normal subgroup of the modular group $\Gamma$, of index $\mu$ and parabolic class number $t$. It is shown that $\mu \leqslant 6 t^{4}$. It follows immediately from this that there are only a finite number of normal subgroups with given parabolic class number. This is in sharp contrast to the case of non-normal subgroups. For it is known that for any integer $t \geqslant 1$, there are infinitely many subgroups of finite index with $t$ parabolic classes. It is also shown that if $p$ is a prime such that $p \equiv-1(\bmod 3)$, then there are no normal subgroups with $p$ parabolic classes.

Key Words: Modular group, quotient surface, factor set, group extension, split extension, parabolic class number, level.

Comparison of three spin algebras employed in SU(6) theories, R. C. Casella, Phys. Rev. 147, No. 4, 962-964 (July 29, 1966).

The Lipkin Meshkov W spin, Foldy Wouthuysen mean spin, and an algebra constructed from the four generators of the Wigner little group provide $\mathrm{SU}(2)$ algebras which can be imbedded in an $\mathrm{SU}(6)$ description of moving hadrons. It is shown that when acting on particle states obeying the Dirac equation, all three are identical. Differences occur with regard to behavior under charge conjugation. In particular, the FW spin acts on particles and anti-particles alike and, in the quark model does not lead to the LM spin flip between the vector and pseudoscalar mesons.

Key Words: Hadrons, little group, spin algebras, SU(6), W spin.

Fundamental polygons for Fuchsian groups, L. Greenberg, J. Anal. Math. 18, 99-105 (1967).

It is proved that a certain class of fundamental polygons for finitely generated Fuchsian groups are finite-sided. This is already known for convex polygons. However, this paper gives a much shorter proof for a wider class of polygons.

Key Words: Fuchsian group, fundamental polygon, simple fundamental polygon, $F$-regular region, horocyclic region, hypercyclic region.

Fundamental polyhedra for Kleinian groups, L. Greenberg, Ann. Math. 84, No. 3, 433-441 (Nov. 1966).

The following theorem is proved: Let $\Gamma$ be a Kleinian group whose limit set contains at least two points. If $\Gamma$ has a fundamental polyhedron (in hyperbolic 3 -space) with a finite number of sides, then the region of discontinuity in the complex plane cannot be connected and simply connected. From this, it follows that there exist finitely generated Kleinian groups which have no finite-sided fundamental polyhedron. This is in surprising contrast to the case of Fuchsian groups.

Key Words: Kleinian group, hyperbolic space, region of discontinuity, limit set, fundamental polyhedron, Euler characteristic.

On a theorem of Ahlfors and conjugate subgroups of Kleinian groups, L. Greenberg, Am. J. Math. LXXXIX, No. 1, 56-68 (Jan. 1967).

A gap in a theorem of L. Ahlfors is filled and a generalization of the problem is studied.

Key Words: Kleinian group, region of discontinuity, parabolic triangle group, Hilbert nullstellensatz, prime ideal, Fuchsian group, conjugate subgroups.

Representations of discrete groups, J. Lehner, Proc. Symp. Pure Mathematics, California Institute of Technology, Pasadena, Calif., Nov. 21-22, 1963, Chapt. VIII, Theory of Numbers, pp. 203-208 (American Mathematical Society, Providence, Rhode Island, 1965).

It is shown that certain properties of a class of finitely generated abstract groups known as $F$-groups are preserved when the $F$. group is imbedded in $\mathrm{SL}(2$, reals) as a discrete matrix subgroup. Thus the abstract structure of the $F$-group determines to a certain extent the topological properties of the matrix group.

Key Words: Abstract groups, finitely generated abstract groups, $F$-groups, discrete matrix group, representations of discrete groups.

\section{Other NBS Publications}

J. Res. NBS 71 A (Phys. and Chem.), No. 4 (July-Aug. 1967), $\$ 1.00$.

Kinetics of crystallization in multicomponent systems: I. Binary mixtures of $n$-paraffins. J. I. Lauritzen, Jr., E. Passaglia, and E. A. DiMarzio.

Kinetics of crystallization in multicomponent systems: II. Chainfolded polymer crystals. J. I. Lauritzen, Jr., and E. Passaglia.

Infrared absorption spectra of 2-oxo-1,3-bis(phenylhydrazono) derivatives and related bis- and tris-phenylhydrazones. A. J. Fatiadi.

Dielectric constant of $n$-hexane as a function of temperature, pressure, and density. F. I. Mopsik.

Heat capacities and related thermal data for diethyl phthalate crystal, glass, and liquid to $360^{\circ} \mathrm{K}$. S. S. Chang, J. A. Horman, and A. B. Bestul.

Heats of formation of aluminum diboride and $\alpha$-aluminum dodecaboride. E. S. Domalski and G. T. Armstrong.

Effect of environment upon the melting point of $\mathrm{Al}_{2} \mathrm{O}_{3}$. S. J. Schneider and C. L. McDaniel.

J. Res. NBS 71 A (Phys. and Chem.), No. 5 (Sept.-Oct. 1967), $\$ 1.00$.

Zeeman effect in positronium annihilation at low temperatures. W. C. Sauder and R. D. Deslattes.

Surface-layer relaxation in the dielectric spectrum of $\mathrm{CaF}_{2}$ doped with $\mathrm{GdF}_{3}$. A. D. Franklin, S. Marzullo, and J. B. Wachtman, Jr. Thermal expansion of rutile from 100 to $700^{\circ} \mathrm{K}$. R. K. Kirby. 
Mass spectrometric study of photoionization. VII. Nitrogen dioxide and nitrous oxide. V. H. Dibeler, J. A. Walker, and S. K. Liston. Ionization constants of substituted benzoic acids in ethanol-water. G. M. Brauer, G. Durany, and H. Argentar.

Dissociation constants of some substituted nitrophenols in aqueous solution at $25{ }^{\circ} \mathrm{C}$. R. A. Robinson.

\section{J. Res. NBS 71 A (Phys. and Chem.), No. 6 (Nov.-Dec. 1967), $\$ 1.00$.}

\section{Guest Editor: C. H. Corliss}

William Frederick Meggers, A Tribute. K. G. Kessler.

The second spectrum of ytterbium (Yb II). W. F. Meggers. (Edited by C. E. Moore.)

An improved description of technetium spectra (Tc I and Te II), 2000 to $9000 \AA$. W. R. Bozman, W. F. Meggers, and C. H. Corliss.

Lifetimes of energy levels in neutral iron. C. H. Corliss and J. L. Tech.

Transition probabilities in argon I. C. H. Corliss and J. B. Shumaker, Jr.

The fifth spectrum of praseodymium. V. Kaufman and J. Sugar.

Fundamental energy levels of neutral promethium (Pm I). J. Reader and S. P. Davis.

\section{J. Res. NBS 71 C (Eng. and Instr.), No. 3 (July-Sept. 1967),} 75 cents.

Procedure for high precision density determinations by hydrostatic weighing. H. A. Bowman and R. M. Schoonover with Appendix by M. W. Jones.

Study of the storage stability of the barium fluoride film electric hygrometer element. F. E. Jones.

Torsion creep of circular and noncircular tubes. L. Mordfin.

Digitized low-frequency phasemeter assembled from logic modules. J. E. McKinney.

\section{J. Res. NBS $71 \mathrm{C}$ (Eng. and Instr.), No. 4 (Oct.-Dec. 1967),} 75 cents.

Measurements of the thermal conductivity and electrical resistivity of platinum from 100 to $900{ }^{\circ} \mathrm{C}$. D. R. Flynn and M. E. O'Hagan.

Thermal conductivity and electrical resistivity of Armco iron. T. W. Watson, D. R. Flynn, and H. E. Robinson.

Heat flow in a right circular cylinder with internal heat generationapplications to the determination of thermal conductivity. D. R. Flynn.

Radiation-induced acoustic cavitation; apparatus and some results. M. Greenspan and C. E. Tschiegg.

Design of a new Kossel pattern generator. D. L. Vieth and $\mathrm{H}$. Yakowitz.

The near-zone magnetic field of a small circular-loop antenna. F. M. Greene.

Analytical coordination chemistry; titrimetry, gravimetry, flame photometry, spectrophotometry, gas evolution and isotopic preparations, July 1965 to June 1966, Ed. O. Menis, Tech. Note 402 (July 21, 1967), 50 cents.

Automatic typographic-quality typesetting techniques: a state-ofthe-art revıew, M. E. Stevens and J. L. Little, Mono. 99 (April 7, 1967), 70 cents.

Bibliography and index on vacuum and low pressure measurement. January 1960 to December 1965, W. G. Brombacher, Mono. 35 Supplement 1 (May 31, 1967), 65 cents.

Bibliography of Liesegang rings (second edition), K. H. Stern, Misc. Publ. 292 (Sept. 1, 1967), 40 cents.

Bibliography of temperature measurement, July 1960 to December 1965, L. O. Olsen and C. Halpern, Mono. 27, Supplement 2 (April 28, 1967), 35 cents (Supersedes Supplement 1 to Monograph 27).

Colors of signal lights. Their selection, definition, measurement, production, and use, F. C. Breckenridge, Mono. 75 (April 3, 1967), 40 cents.

Connector for saturated standard cells, J. J. Barth, Tech. Note 353 (April 21, 1967), 10 cents.

Directory of United States standardization activities, J. E. Hartman, Misc. Publ. 288 (Aug. 1, 1967), \$2.00. (Supersedes Misc. Publ. 230.)

Discussion of errors in gain measurements of standard electromagnetic horns, R. W. Beatty, Tech. Note 351 (March 1967), 30 cents.
Drawings of micrometer U-tube manometers for the ranges up to $100 \mathrm{~mm}$ of mercury, A. M. Thomas and J. L. Cross, Tech. Note 420 (Aug. 26, 1967), 15 cents.

Effects of finite lattice heat capacity on spin-lattice relaxation theory and numerical analysis, R. L. Peterson, Mono. 102 (Aug. 1, 1967), 25 cents.

Grading of abrasive grain on coated abrasive products, PS8-67 (Jan. 9, 1967), 15 cents. (Supersedes CS217-59.)

Hardboard, CS251-63, reprinted April 1967 with amendments (Nov. 15, 1966), 10 cents.

NBS standard frequency and time services. Radio stations WWV, WWVH, WWVB, WWVL, Misc. Publ. 236, 1967 Edition (1967), 15 cents.

Nuclear science and technology for ceramists, Proceedings of the American Ceramic Society Symposium, Washington, D.C., April 7-12, 1966. Misc. Publ. 285 (May 26, 1967), \$1.75.

Proceedings of the 1966 Standards Laboratory Conference, Misc. Publ. 291 (July 13, 1967), \$1.00.

Quantum mechanical calculations of the second virial coefficients for hydrogen, M. E. Body and S. Y. Larsen, Tech. Note 412 (April 10, 1967), 15 cents.

Quantitative methods for management, G. Suzuki, Tech. Note 414 (May 23, 1967), 25 cents.

Report of the 5lst National Conference on weights and measures, 1966, Report Ed. L. J. Chiholm, Misc. Publ. 290 (May 15, 1967), $\$ 1.00$.

Revision of the NBS tables of spectral-line intensities below $2450 \AA$. C. H. Corliss, Mono. 32 Supplement (July 7, 1967), 30 cents.

Softwood plywood, construction and industrial, Prod. Std. 1-66 (November 1, 1966), 20 cents (Supersedes Commercial Standards $45-60,122-60$, and 259-63).

Standard Reference Materials: Mossbauer spectroscopy standard for the chemical shift of iron compounds, J. J. Spijkerman, D. K. Snediker, F. C. Ruegg, and J. R. DeVoe, Misc. Publ. 260-13 (July 28, 1967), 40 cents.

Standard Reference Materials: Recommended method of use of standard light-sensitive paper for calibrating carbon arcs used in testing textiles for color-fastness to light, E. Passaglia and P. J. Shouse, Misc. Publ. 260-15 (July 21, 1967), 20 cents.

Standard stock light-duty $13 / 8$ - and $13 / 4$-inch thick flush-type interior steel doors and frames, Prod. Std. 4-66 (November 1, 1966), 10 cents (Supersedes Commercial Standard 211-57).

Tables relating to Mathieu functions. Characteristic values, coefficients, and joining factors, AMS 59 (Aug. 1, 1967), \$3.25. (a reissue, with additions, of Columbia University Press 13).

Technical highlights of the National Bureau of Standards, annual report 1966, Misc. Publ. 283 (April 1967), 60 cents.

Technology and world trade. Proceedings of a symposium, Ed. by R. L. Stern, Misc. Publ. 284 (1967), \$1.25.

Thermal radiation property measurement techniques, S. T. Dunn, J. C. Geist, D. G. Moore, H. E. Clark, and J. C. Richmond, Tech. Note 415 (April 27, 1967), 50 cents.

Thermal-shock resistance for built-up membranes, W. C. Cullen and T. H. Boone, Bldg. Sci. Series 9 (Aug. 21, 1967), 20 cents.

The single-engine Claude cycle as a $4.2^{\circ} \mathrm{K}$ refrigerator, R. C. Muhlenhaupt and T. R. Strobridge, Tech. Note 354 (June 1, 1967), 45 cents.

The solid system. II. Numeric compression, P. A. D. deMaine, K. Kloss, and B. A. Marron, The solid system. III. Alphanumeric compression, P. A. D. deMaine, B. A. Marron, and K. Kloss, Tech. Note 413 (Aug. 15, 1967), 30 cents.

The viscosity and thermal conductivity coefficients of dilute neon, krypton, and xenon, H. J. M. Hanley and G. E. Childs, Tech. Note 352 (March 23, 1967), 25 cents.

Units of weight and measure. International (metric) and U.S. Customary, L. J. Chisholm, Misc. Publ. 286 (May 1967), \$1.50 (Supersedes Miscellaneous Publication 233).

Density and vapor pressure of nitromethane 26 to $200^{\circ} \mathrm{C}, \mathrm{H}$. A. Berman and E. D. West, J. Chem. Eng. Data 12, No. 2, 197-199 (Apr. 1967).

Electrolysis of nonaqueous systems, A. Brenner, Book, Advances in Electrochemistry and Electrochemical Engineering, Ed. C. W. Tobias, chapt. V, pp. 205-248 (John Wiley \& Sons, Inc., New York, N.Y., 1967).

Galvanostalametry: A technique for chemical analysis, A. Brenner and J. L. Sligh, J. Electrochem. Soc. 114, No. 5, 461-465 (May 1967).

Geometry and vibrational spectra of the alkaline-earth dihalides. 
I. $\mathrm{MgF}_{2}$, D. E. Mann, G. V. Calder, K. S. Seshadri, D. White, and M. J. Linevsky, J. Chem. Phys. 46, No. 3, 1138-1143 (Feb. 1, 1967).

Infrared and raman spectra of some trihalide ions: $\mathrm{ICl}_{2^{-}}, \mathrm{IBr}_{2^{-}}, \mathrm{I}_{3^{-}}$, $\mathrm{I}_{2} \mathrm{Br}-$, and BrICl-, A. G. Maki and R. Forneris, Spectrochim. Acta 23A, 867-880 (1967).

Measurements on the molecular nitrogen pulsed laser, T. Kasuya and D. R. Lide, Jr., Appl. Opt. 6, No. 1, 69-80 (Jan. 1967).

Molecular and ionic interactions in dielectrics, W. S. Lovell, Book, 1965 Digest of Literature on Dielectrics 29, chapt. III, pp. 81-198 (National Academy of Sciences, National Research Council, Wash., D.C., 1967).

Novel aromatization of inositols in dimethyl sulphoxide-acetic anhydride, A. J. Fatiadi, Chem. Commun. 9, 441 (May 10, 1967). Generalized integrating-sphere theory, D. G. Goebel, Appl. Opt. 6, No. 1, 125-128 (Jan. 1967).

High order correlations in a turbulent field, F. N. Frenkiel and P. S. Klebanoff, Phys. Fluids 10, No. 3, 507-520 (Mar. 1967).

Space-time correlations in turbulence, F. N. Frenkiel and P. S. Klebanoff (Proc. Symp. Dynamics of Fluids and Plasma, University of Maryland; Oct. 7-9, 1965), Book, Dynamics of Fluids and Plasmas, pp. 257-274 (Academic Press, Inc., New York, N.Y. 1966).

Terms, definitions, and symbols in reflectometry, D. B. Judd, J. Opt. Soc. Am. 5 7, No. 4 445-452 (Apr. 1967).

Collective treatment of the giant resonances in spherical nuclei, M. G. Huber, M. Danos, H. J. Weber, and W. Greiner, Phys. Rev. 155, No. 4, 1073-1084 (Mar. 20, 1967).

Instrumentation and measurements, J. E. Gray and H. E. Bussey, Book, 1965 Digest of Literature on Dielectrics 29, chapt. I, pp. 1-25 (National Academy of Sciences, National Research Council, Wash., D.C. 1967).

Optical heterodyne measurement of neon laser's millimeter wave difference frequency, J. L. Hall and W. W. Morey, Appl. Phys. Letters 10, No. 5, 152-155 (Mar. 1, 1967).

Polarization of cosmic $\mathrm{OH} 18-\mathrm{cm}$ radiation, P. L. Bender, Phys Rev. Letters 18, No. 14, 562-564 (Apr. 3, 1967).

Progress in electron physics during the last 20 years, L. Marton, Third Czechoslovak Conf. Electronics and Vacuum Physics, Prague, Czechoslovakia, Sept. 23-28, 1965, pp. 17-25 (Czechoslovak Academy of Sciences, Prague, Czechoslovakia, 1967).

Random walk with an excluded origin, R. J. Rubin, J. Math. Phys. 8, No. 3, 576-581 (Mar. 1967).

Theory of the magnetic torque anisotropy of the samarium iron garnet, J. A. White, Proc. Phys. Soc. 90, 1095-1109 (1967).

Widths of Kikuchi lines in germanium, H. A. Fowler and L. Marton, J. Appl. Phys. 38, No. 4, 1735-1738 (Mar. 15, 1967).

Adhesive bonding of various materials to hard tooth tissues. IV. Forces developing in direct-filling materials during hardening. R. L. Bowen, J. Am. Dental Assoc. 74, No. 3, 440-445 (Feb. 1967).

Bonding porcelain teeth to acrylic resin denture bases, G. C. Paffenbarger, W. T. Sweeney, and R. L. Bowen, J. Am. Dental Assoc. 74, 1018-1023 (Apr. 1967).

Comparison of direct and sensitized photolysis of 3-methylpentanal in vapor phase, R. E. Rebbert and P. J. Ausloos, J. Am. Chem. Soc. 89, No. 7, 1573-1579 (Mar. 29, 1967).

Conformation of polyesters adsorbed on solid surfaces, P. Peyser, D. J. Tutas, and R. R. Stromberg, J. Polymer Sci. 5, Pt. A-1, 651-663 (1967).

Effects of packing pressures on the properties of spherical alloy amalgams, G. T. Eden and R. M. Waterstrat, J. Am. Dental Assoc. 74, No. 5, 1024-1029 (Apr. 1967).

Flash photolysis of methane in the vacuum ultraviolet. II. Absolute rate constants for reactions of $\mathrm{CH}$ with methane, W. Braun, J. R. McNesby, and A. M. Bass, J. Chem. Phys. 46, No. 6, 20712079 (Mar. 15, 1967).

Flow properties of aqueous suspensions containing kaolins of varying degrees of crystallinity, W. C. Ormsby and J. H. Marcus, J. Am. Ceramic Soc. 50, No. 4, 190-195 (Apr. 1967).

Initial kinetic parameters from thermogravimetric rate and conversion data, J. H. Flynn and L. A. Wall, J. Polymer Sci. Letters 5B, No. 2, 191-196 (Feb. 1967).

NBS hunts for better ways to control corrosion, S. Lichtenstein, Mater. Eng. 65, No. 5, 21-23 (May 1967).

Neutron-scattering study of the motions of water molecules in hydrated salts of transition metals, J. J. Rush, J. R. Ferraro, and A. Walker, Inorg. Chem. 6, No. 2, 346-351 (Feb. 1967).

Reactions of ethylidene in the vacuum ultraviolet photolysis of ethylene, E. Tschuikow-Roux, J. R. McNesby, W. M. Jackson, and J. L. Faris, J. Phys. Chem. 71, No. 5, 1531-1532 (April 1967).

The effect of other metallic ions on the electrocrystallization of silver from nitrate solutions, J. P. Young, Plating 54, No. 3, 272-274 (Mar. 1967).

The relationship between laboratory tests on solubility of zinc oxideeugenol type cement and their behavior in the mouth, G. M. Brauer, N.Y. J. Dentistry 37, No. 4, 146 (Apr. 1967).

A new service by NBS. An aid in making the Bureau's technical resources available to private standards organizations, manufacturers, and government agencies, G. S. Gordon, Proc. 15th Annual Meeting Standards Engineering Society, Atlantic City, N.J., Sept. 14, 1966, pp. 73-75 (1966).

Absolute calibration of vibration generators with time-sharing computer as integral part of system, B. F. Payne, Shock Vibration Bull. 36, Pt. 6, 183-194 (Feb. 1967).

Cathodic protection of copper in a severely corrosive soil, W. J. Schwerdtfeger, IEEE Trans. Ind. Gen. Appl. IGA-3, No. 1, 66-69 (Jan.-Feb. 1967).

Electrical feedthrough for pressures to $10 \mathrm{kbar}$, P. L. M. Heydemann, Rev. Sci. Instr. Laboratory Notes 38, No. 4, 558-559 (Apr. 1967).

Ellipsometric errors due to multiple reactions in mica quarter-wave plates, H. T. Yolken, R. M. Waxler, and J. Kruger, J. Opt. Soc. Am. 57, No. 2, 282-284 (Feb. 1967).

Evaluation of a stark voltmeter, Y. Beers and T. W. Russell, IEEE Trans. Instr. Meas. IM-15, No. 4, 380-388 (Dec. 1966).

Improved transfer standard for vibration pickups, E. Jones, D. Lee, and S. Edelman, J. Acoust. Soc. Am. 41, No. 2, 354-357 (Feb. 1967).

Introduction, J. M. Richardson, (Proc. 1966 Conf. Precision Electromagnet Measurements, Boulder, Colorado, June 21-23, 1966), IEEE Trans. Instr. Meas. IM-15, No. 4, 138 (Dec. 1966).

Stress-corrosion cracking of cold-reduced austenitic stainless steels, H. L. Logan and M. J. McBee, Mater. Res. Std. 7, No. 4, 137-145 (Apr. 1967).

Anniversaries in 1966-67 of interest to statisticians Part I: Introduction and summary, C. Eisenhart, Am. Stat. 21, No. 2, 32-34 (Apr. 1967).

Comments on presentation by Albert A. Anctil, J. R. Rosenblatt, (Proc. 11th Conf. Design of Experiments in Army Research Development and Testing, Dover, N.J., Oct. 20-22, 1965), U.S. Army ARO-D Report 66-2, pp. 509-510 (U.S. Army Research Office, Durham, N.C.. May 1966).

An intercomparison of hydrogen and cesium frequency standards, R. Vessot, H. Peters, J. Vanier, R. Beehler, D. Halford, R. Harrach, D. Allan, D. Glaze, C. Snider, J. Barnes, L. Cutler, and L. Bodily, IEEE Trans. Instr. Meas. IM-15, No. 4, 165-176 (Dec. 1966).

Interval scales, ratio scales, and additive scales for the sizes of differences perceived between members of a geodesic series of colors, D. B. Judd, J. Opt. Soc. Am. 57, No. 3, 380-386 (Mar. 1967).

Reflectance spectrophotometry, D. B. Judd, Encyclopedia of Industrial Chemical Analysis 3, 376-392 (John Wiley \& Sons, Inc., New York, N.Y.. 1966).

The national measurement systems of various countries, H. W. Lance, IEEE Trans. Instr. Meas. IM-15, No. 4, 397-403 (Dec. 1966).

The variability of color measurement, I. Nimeroff, Color Eng. 5, No. 2, 24-29 (Mar.-Apr. 1966).

Thermal converters for audio-frequency voltage measurements of high accuracy, F. L. Hermach and E. S. Williams, IEEE Trans. Instr. Meas. IM-15, No. 4, 260-268 (Dec. 1966).

WWV moves to Colorado. Part I, Y. Beers, QST 51, No. 1, 11-14 (Jan. 1967): Part II, QST 51, No. 2, 30-35 (Feb. 1967).

An optical power limiter, B. L. Danielson, Appl. Opt. 6, No. 1, 158-159 (Jan. 1967).

Autoionization spectra of the noble gases, R. P. Madden and K. Codling (Proc. Symp. Atomic Interactions and Space Physics, Goddard Space Flight Center, Greenbelt, Maryland, Aug. 10-11, 1965), Book, Autoionization: Astrophysical, Theoretical, and Laboratory Experimental Aspects, pp. 129-151 (Mono Book Corp., Baltimore, Md., 1966)

Chromatic changes induced by changes in chromaticity of background of constant lightness, H. Takasaki, J. Opt. Soc. Am. 57, No. 1, 93-96 (Jan. 1967).

Comments on "Nature of the critical nucleus in heterogeneous vapor-solid nucleation," A. J. Melmed and S. C. Hardy, Surface Sci. 6, No. 4, 481-482 (April 1967). 
Compensation and band tailing effects in high power room temperature GaAs lasers, N. N. Winogradoff and H. K. Kessler, SolidState Communications 5, 155-158 (Pergamon Press Ltd., London, England, 1967).

Correlation of spherical aberration of axially symmetrical magnetic lenses, L. Marton, Rev. Sci. Instr. 38, No. 1, 130-131 (Jan. 1967).

Correlation of large longitudinal deformations with different strain histories, L. J. Zapas and T. Craft, Rubber Chem. Technol. 40, No. 2, 506-516 (Mar. 1967).

Dislocation node determinations of the stacking fault energy in silver-tin alloys, A. W. Ruff, Jr., and L. K. Ives, Acta Met. 15, 189-198 (Feb. 1967).

Electron monochromator design, C. E. Kuyatt and J. A. Simpson, Rev. Sci. Instr. 38, No. 1, 103-111 (Jan. 1967).

Estimate of extrinsic stacking-fault energies from dislocation configurations, W. F. Hartl, R. deWit, and R. E. Howard, J. Appl Phys. 38, No. 1, 1-4 (Jan. 1967).

Excitation and ionization in arc and spark spectroscopic sources, M. Margoshes, Appl. Spectry. 21, No. 2, 92-99 (1967).

Interpretation of ferromagnetic resonance measurement made in a nonresonant system, A. S. Risley and H. E. Bussey, IEEE Trans. Instr. Meas. IM-15, No. 4, 393-396 (Dec. 1966).

Is proton channeling a diffraction process? $\mathrm{H}$. A. Fowler and C. Erginsoy, Physics Letters 24A, No. 7, 390-391 (Mar. 27, 1967)

Kinetics of solute-enhanced diffusion in dilute face-centered-cubic alloys, R. E. Howard and J. R. Manning, Phys. Rev. 154, No. 3 , 561-568 (Feb. 1967).

Measurement of thermal neutron flux, R. S. Carter, C. O. Muehlhause, and V. W. Myers, IEEE Trans. Nucl. Sci. NS-14, No. 1 414-415 (Feb. 1967).

Molecular thermodynamics of simple liquids, mixtures, C. A Eckert, H. Renon, and J. M. Prausnitz, I \& EC Fundamentals 6 No. 1, 58-67 (Feb. 1967).

Molecular thermodynamics of simple liquids, pure components, H. Renon, C. A. Eckert, and J. M. Prausnitz, I \& EC Fundamentals 6, No. 1, 52-58 (Feb. 1967).

Rare-gas collision broadening in the lowest ${ }^{3} \mathrm{P}_{1}$ level of $\mathrm{Cd}, \mathrm{R} . \mathrm{L}$. Barger, Phys. Rev. 154, No. 1, 94-97 (Feb. 5, 1967).

Recombination of $\mathrm{He}^{+}$and $\mathrm{He}^{++}$in the afterglow of a helium discharge, E. R. Mosburg, Jr., Phys. Rev. 152, No. 1, 166-176 (Dec. 2,1966 ).

Second breakdown and crystallographic defects in transistors, H. A. Schafft, G. H. Schwuttke, and R. L. Ruggles, Jr., IEEE Trans. Electron Devices ED-13, No. 11, 738-742 (Nov. 1966).

Simultaneous diffraction with the three-circle diffractometer, M. Zocchi and A. Santoro, Acta Cryst. 22, Pt. 3, 331-334 (Mar. 1967).

Some aspects of the photodisintegration of light nuclei, E. Hayward, Proc. Intern. School of Physics "Enrico Fermi", Course XXXVI, Ed. C. Bloch, July-Aug. 1965, Monastero, Italy, pp. 559-565 (Academic Press Inc., London, England, 1966).

Some experiments with Zeeman shifted levels, K. G. Kessler, (Proc. Zeeman Centennial Conf., Amsterdam, The Netherlands, Sept. 9-11, 1965), Physica 33, 29-46 (1967).

Some relations for straight dislocation, R. deWit, Phys. Stat. Sol. 20 , 567-573 (1967).

Specific heat of natural rubber and other elastomers above the glass transition temperature, L. A. Wood and N. Bekkedahl, J. Polymer Sci. Letters 5, 169-175 (1967).

The self-energy of dislocation configurations made up of straight segments, R. deWit, Phys. Stat. Soc. 20, 575-580 (1967).

The small-angle limit for twice-scattered gamma rays from a point isotropic source, E. E. Morris and L. V. Spencer, Nucl. Sci. Eng. 27, 485-488 (Feb. 1967).

The stacking-fault energy in alpha-silver-tin alloys, A. W. Ruff, Jr and L. K. Ives, Can. J. Phys. 45, 787-795 (1967).

Vibrational analysis of $\mathrm{SeF}_{6}$ and $\mathrm{WF}_{6}, \mathrm{~S}$. Abramowitz and I. W Levin, Inorg. Chem. 6, 538-541 (1967).

Calorimetry, G. T. Armstrong, 1967 McGraw-Hill Yearbook of Science and Technology, pp. 124-127 (1967).

Charge-transfer spectrum of the tetrachlorocuprate ion, M. Sharnoff and C. W. Reimann, J. Chem. Phys. 46, No. 7, 2634-2640 (Apr. 1, 1967).

Correlation of some Precambrian rocks and metamorphic events in parts of Wyoming and Montana, E. J. Catazaro, Mt. Geol. 4, No. 1, 9-21 (1967).

Determination of trace elements in standard reference materials by neutron activation analysis, G. W. Smith, D. A. Becker, G. J.
Lutz, L. A. Currie, and J. R. DeVoe, Anal. Chim. Acta 38, 333340 (1967).

Distillation as a tool for purification of research quantities of material, R. T. Leslie, Ann. N. Y. Acad. Sci. 137, 19-29 (1966).

Erratum: Mass-spectrometric study of the reactions of $\mathrm{O}$ atoms with $\mathrm{NO}$ and $\mathrm{NO}_{2}$, F. S. Klein and J. T. Herron, J. Chem. Phys. 44, No. 9, 3645-3646 (May 1, 1966)

Gas phase radiolysis of cyclobutane, R. D. Doepker and P. Ausloos, J. Chem. Phys. 44, 1641-1647 (Feb. 1966).

Investigating ion-molecule reactions by analyzing neutral products formed in the radiolysis and photoionization of hydrocarbons, P. Ausloos, S. G. Lias, and A. A. Scala, Adv. Chem. Ser. 58, 264-277 (1966).

Magnetic and optical spectra of two dimeric copper-chloride pyridine- $N$-oxide complexes, G. F. Kokoszka, H. C. Allen, Jr., and G. Gordon, J. Chem. Phys. 48, No. 8, 3020 (Apr. 1967).

Mass spectrometric study of the photoionization of small molecules, V. H. Dibeler, R. M. Reese, and M. Krauss (Proc. 3d Intern. Conf. Mass Spectrometry, Paris, France, Sept. 1964), Book, Advances in Mass Spectrometry 3, 471-488 (Institute of Petroleum, London, England, 1966).

Measurement of the direct $l$-doublet transitions in carbonyl sulfide, A. G. Maki, J. Mol. Spectry. 23, No. 1, 110-111 (May 1967).

Microtexture and composition of reaction products in the system kaoline-lime-water, W. C. Ormsby and L. A. Bolz, J. Am. Ceram. Soc. 49, No. 7, 364-366 (July 1966).

Microwave spectroscopy, D. R. Lide, Jr., Encyclopedia of Industrial Analysis 2, 600-611 (John Wiley and Sons, Inc., New York, N.Y., 1966).

Microwave spectrum of excited vibrational states of FCN, W. J. Lafferty and D. R. Lide, Jr., J. Mol. Spectry. 23, No. 1, 94-96 (May 1967).

Microwave spectrum, structure, dipole moment, and barrier to internal rotation of phosphorus trifluoride-borane, R. L. Kuczkowski and D. R. Lide, Jr., J. Chem. Phys. 46, No. 1, 357-365 (Jan. 1967).

Microwave studies of rotational isomerism, D. R. Lide, Jr., Trans. Am. Cryst. Assoc. 2, 106-116 (1966).

Monomer-polymer equilibria of deuterated alpha-methylstyrenes, L. J. Fetters, W. J. Pummer, and L. A. Wall, J. Polymer Sci. 4, Part A-1, 3003-3011 (1966).

Mossbauer spectroscopy: applications to aerospace, J. R. DeVoe and J. J. Spijkerman, Book, Radioisotopes for Aerospace, Part 2, Systems and Applications, pp. 254-269 (Plenum Press Inc., New York, N.Y., 1966)

Needs of American Chemical Society members for property data, H. M. Weisman, J. Chem. Doc. 7, No. 1, 10-14 (Feb. 1967).

Nuclear magnetic relaxation studies of $\left(\mathrm{CD}_{3} \mathrm{O}\right)_{2}{ }^{11} \mathrm{BH}, \mathrm{N}$. Boden, H. S. Gutowsky, J. R. Hansen, and T. C. Farrar, J. Chem. Phys. 46, No. 7, 2849 (Apr. 1, 1967).

Photolysis of cyclopentane at 1470, 1236, and 1048-67 A, R. D. Doepker, S. G. Lias, and P. Ausloos, J. Chem. Phys. 46, No. 11, 4340-4346 (June 1, 1967).

Radiation and photochemistry, P. Ausloos, Ann. Rev. Phys. Chem. 17, 205-236 (1966),

Simultaneous determination of copper and zinc in human lung tissue by neutron activation analysis, R. G. Keenan, J. H. Marcus, and J. R. DeVoe, Am. Ind. Hygiene Assoc. J. 27, 128-134 (Mar.Apr. 1966).

Sublimation, E. C. Kuehner and R. T. Leslie, Encyclopedia of Industrial Chemical Analysis 3, 573-584 (1966).

Symposium on problems of small information groups. Introductory remarks, M. B. Henderson (Div. Chem. Lit. Symp. Problems of Small Information Groups, 151st Natl. Meeting Am. Chem. Soc., Pittsburgh, Pa., Mar. 25, 1966), J. Chem. Doc. 6, 143 (Aug. 1966). Systematic errors in "recovery" and "detection" efficiency as related to radiochemical analysis, L. A. Currie, Proc. 11th Annual Bio-Assay and Analytical Chemistry Meeting, Albuquerque, New Mexico, Oct. 7-8, 1965, AEC No. 651008, pp. 35 (Clearinghouse for Federal Scientific and Technical Information, Springfield, Va., 1967).

The chain decomposition of propane initiated by vacuum ultraviolet photolysis, A. H. Laufer and J. R. McNesby, J. Phys. Chem. 70, 4094-4096 (1966).

The crystal structure of sodium tetraborate, A. Hyman, A. Perloff, F. Mauer, and S. Block, Acta Cryst. 22, No. 6, 815-821 (June 1967).

The determination of bound styrene soluble high styrene-butadiene 
resins, M. A. Post, J. Paint Technol. 38, No. 497, 336-342 (June 1966).

The microwave spectrum and dipole moment of pyrazole, W. $\mathrm{H}$. Kirchhoff, J. Am. Chem. Soc. 89, No. 6, 1312-1316 (Mar. 1967). The microwave spectrum, structure, dipole moment, and quadrupole coupling constants of trans-nitrous acid, A. P. Cox and R. L. Kuczkowski, J. Am. Chem. Soc. 88, No. 22, 5071-5074 (Nov. 1966).

Thermal decomposition of 4,4-dimethylpentene-1 in a single-pulse shock tube, W. Tsang, J. Chem. Phys. 46, No. 7, 2817-2822 (Apr. 1, 1967).

Two National Bureau of Standards data centers: chemical kinetics and mass spectrometry, D. Garvin and H. M. Rosenstock, J. Chem. Doc. 7, No. 1, 31-34 (Feb. 1967).

Vacuum-ultraviolet photolysis of solid propane at $20^{\circ}$ and $77{ }^{\circ} \mathrm{K}$, R. E. Rebbert and P. Ausloos, J. Chem. Phys. 46, No. 11, 43334339 (June 1967).

Vapor deposition of tungsten by hydrogen reduction hexafluoride process variables and properties of the deposit, J. F. Berkeley, A. Brenner, and W. E. Reid, Jr., J. Electrochem. Soc. 114, No. 6, 561-568 (June 1967).

A new ultra-low-frequency bridge for dielectric measurements, W. P. Harris, 1966 Annual Report, Conf. Electrical Insulation and Dielectric Phenomena, National Academy of Sciences-National Research Council, Mount Pocono, Pa., 1966, pp. 72-74.

A $100 \mathrm{Mc} / \mathrm{s} 2$ out of 3 gate, J. K. Whittaker, Nucl. Instr. Methods 45, No. 1, 138-140 (Nov. 1966).

A single axis, two crystal x-ray instrument, R. D. Deslattes, Rev. Sci. Instr. 38, No. 6, 815-820 (June 1967).

A testing and rating method for refrigerated trucks with respect to cooling load, P. R. Achenbach, C. W. Phillips, and R. W. Penny, Annex to Proc. Intern. Inst. Refrigeration, Comm. VII, pp. 29-35 (London, England, Sept. 1966).

Two-crystal, vacuum monochromator, R. D. Deslattes, Rev. Sci. Instr. 38, No. 5, 616-620 (May 1967).

Air-to-air heat pumps for military housing, Military Engr. 384, 270 (July-Aug. 1966).

An improved transportable 10 picofarad capacitor, R. D. Cutkosky and L. H. Lee, Proc. $11^{\mathrm{e}}$ Session, Comite Con. D'Electricite, May 10-12, 1965, pp. 65-66 (May 1965).

Comparison of the Hall-Petch parameters of zone-refined iron determined by the grain size and extrapolation methods, B. W. Christ and G. V. Smith, Acta Met. 15, 809-816 (May 1967).

Discussion of the paper "flow in culverts and related design philosophies", J. L. French, J. Hydraulics Div. Am. Soc. Civil Eng. 93, No. HY1, 85-91 (Jan. 1967).

Five years of VLF worldwide comparison of atomic frequency standards, B. E. Blair, E. L. Crow, and A. H. Morgan, Radio Sci. 2, No. 6, 627-636 (June 1967).

Performance criteria for building components and systems, P. R. Achenbach, Proc. Porcelain Enamel Institute Forum, University of Illinois, Urbana, Ill., Sept. 28-30, 1966, 28, 176-195 (1966).

The $\mathrm{Bi}$ I-II transition pressure measured with a dead-weight piston gauge, P. L. M. Heydemann, J. Appl. Phys. 38, No. 6, 2640-2644 (May 1967)

Transistorized current stabilizer for x-ray tubes with directly heated cathodes, K. W. Yee and R. D. Deslattes, Rev. Sci. Instr. 38, No. 5, 637-638 (May 1967).

Anniversaries in 1966-67 of interest to statisticians. Part II: Tercentennials of Arbuthnot and De Moivre, C. Eisehnart and A. Birnbaum, Am. Stat. 21, No. 3, 22-29 (June 1967).

Computer aided typesetting, W. R. Bozman, Book, Advances in Computers, 7, chapt. 4, 195-207 (Academic Press, Inc., New York, N.Y., 1966).

Invariance of the homology of a lattice, J. Mather, Proc. Am. Math. Soc. 17, No. 5, 1120-1124 (Oct. 1966)

On conjugate subgroups of kleinian groups, L. Greenberg, Am. J. Math. LXXXIX, No. 1, 56-68 (Jan. 1967).

A comparator for thermal AC-DC transfer standards, R. S. Turgel, Proc. 21st Annual ISA Conference and Exhibit, New York, N.Y., Oct. 24-27, 1966, ISA Preprint 12.3-1-66 (Oct. 1966).

Calibration of germanium thermometers from 2 to $20^{\circ} \mathrm{K}, \mathrm{G}$. Cataland and H. H. Plumb (Proc. Intern. Inst. Refrigeration, Commission 1, Boulder, Colorado, 1966, Annexe 1966-5), Suppl. Bull. Inst. Intern. Froid, pp. 153-163 (Louvain, Belgium, 1966).

Calibration of the NBS photoelectric pyrometer of 1961, R. D. Lee, Proc. 7th session, Comite Con. de Thermometrie, Paris, France, pp. 74-78 (Sept. 24, 1964).
Cryogenic thermocouple thermometry, L. L. Sparks and R. L. Powell, Meas. Data 1, No. 2, 82-90 (Mar.-Apr. 1967).

International standardization and expanded world trade, A. V. Astin, Mag. Std. 37, No. 7, 191-194 (July 1966).

On long-term stability of Zener reference diodes, W. G. Eicke, Jr., and H. H. Ellis, Proc $11^{\mathrm{e}}$ Session, Comite Con. D'Electricite, May 10-12, 1965, pp. E-73-E-77 (May 1965).

Potential applications of the x-ray/density method for the comparison of atomic-weight values, R. D. Deslattes, H. S. Peiser, J. A. Bearden, and J. S. Thomsen, Metrologia 2, No. 3, 103-111 (July 1966).

Review of elementary theory of the photometry of projection apparatus, C. S. Douglas, Illum. Eng. 62, No. 4, 246-253 (Apr. 1967).

Statistical concepts in metrology, H. H. Ku, Book, Handbook of Industrial Metrology, chapt. 2, pp. 20-54 (Prentice-Hall, Inc., Englewood Cliffs, N.J., 1967).

The photometry of colored light, A. C. Wall, Illum. Engr. 62, No. 4 , 239-242 (Apr. 1967).

Thermal converters used as transfer standards for the measurement of alternating current and voltage, F. L. Hermach, Proc. $11^{\mathrm{e}}$ Session, Comite Con. D’Electricite, May 10-12, 1965, pp. E-83-E-88 (May 1965).

Use of a laser for length measurement by fringe counting, Metrologia 2, No. 3, 95-98 (July 1966).

A note on thermal expansion coefficients of rare gas solids, R. D. Mountain, J. Phys. Chem. Solids 28, 1071-1073 (Dec. 29, 1966).

A simple and accurate method of calibration by photopeak efficiencies, J. M. R. Hutchinson and D. H. Walker, Intern. J. Appl. Radiation Isotopes 18, No. 1, 86-89 (Jan. 1967).

Additional stopping power and range tables for protons, mesons and electrons, M. J. Berger and S. M. Seltzer, NASA-SP-3036 (1966).

Alpha gamma angular correlations in three heavy odd-A nuclides, J. M. R. Hutchinson, Phys. Rev. 157, No. 4, 1093-1098 (May 1967).

Annual report on spectroscopy, C. E. Moore, Astron. J. 71, No. 9, 796-797 (Nov. 1966).

Approximate eigenfunctions of the Louville operator in classical many-body systems. II. Hydrodynamic variables, R. J. Nossal and R. Zwanzig, Phys. Rev. 157, No. 1, 120-126 (May 5, 1967).

Autoionizing D states in He below the $n-2$ level of He, J. W. Cooper, S. Ormonde, C. H. Humphrey, and P. G. Burke, Proc. Phys. Soc. 91, 285-287 (1967).

Certificates of radioactivity standards, S. B. Garfinkel, A. P. Baerg, and P. E. Zigman, Report of the Subcommittee on the Use of Radioactivity Standards, Natl. Acad. Sci.-Natl. Res. Council, pp. 1-11 (Washington, D.C., Dec. 1966).

Cold-neutron study of hindered rotations in solids and liquid methyl chloroform, neopentane and ethane, J. J. Rush, J. Chem. Phys. 46, No. 6, 2285-2291 (Mar. 1967).

Conformation of adsorbed polystyrene measured by attenuated total reflection in the ultraviolet region, $P$. Peyser and $R$. R. Stromberg, J. Phys. Chem. 71, No. 7, 2066-2074 (June 1967). Correction of some erroneous calculations of the Einstein A coefficient for the $18 \mathrm{~cm}$ transition of $\mathrm{OH}, \mathrm{D}$. R. Lide, Jr., Nature 213 , No. 5077, 694-695 (Feb. 18, 1967).

Deformation twinning in $\mathrm{Ni}$ and F.C.C. Fe-Ni alloys, R. P. Reed, Phil. Mag. 15, No. 137, 1051-1055 (May 1967).

Dependence of 50 and $100 \mathrm{keV}$ bremsstrahlung on target thickness, atomic number, and geometric factors, R. C. Placious, J. Appl. Phys. 38, No. 5, 2030-2038 (Apr. 1967).

Development of the engineering method and some simplified methods of structure shielding analysis, C. Eisenhauer (Lecture Notes, OCD Summer Inst., Kansas State Univ., Manhattan, Kansas, 1962-1963, 1965), TR-40, Radiation Shielding-Analysis and Design Principles as Applied to Nuclear Defense Planning, V-1-V-iv (Supt. Docs. Govt. Printing Office, Washington, D.C., Nov. 1966).

Dielectric constants of $\mathrm{PbWO}_{4}$ and $\mathrm{CaWO}_{4}, \mathrm{~W}$. S. Brower and P. H. Fang, J. Appl. Phys. 38, No. 5, 2391 (Apr. 1967).

Effect of oxygen on the photoelectron yield from tungsten in the vacuum ultraviolet, B. J. Waclawski, L. R. Hughey, and R. P. Madden, Appl. Phys. Letters 10, 305 (1967).

Effects of environment on the fracture of glass, S. M. Wiederhorn, Proc. RIAS Conf., Baltimore, Md., June 7-8, 1965, pp. 293-317 (Gordon and Breach, New York, N.Y., 1966).

Eigenchannel theory of nuclear reactions, M. Danos and W. Greiner, Phys. Rev. 146, No. 3, 708-712 (June 1966). 
Electron beams: National Bureau of Standards and the new technology, H. W. Kock, Science 156, No. 3773, 321-328 (Apr. $21,1967)$.

Experimental evidence concerning the conduction band of $\mathrm{SrTiO}_{3}$, H. P. R. Frederiske, W. R. Hosler, and W. R. Thurber (Proc. Intern. Conf. Physics of Semiconductors, Kyoto, Japan, Sept. 8-13, 1966), J. Phys. Soc. 21, Suppl., 32-36 (1966).

Exposure rate measurements of $\mathrm{X}$ - and gamma-rays with silicon radiation detectors, K. Scharf, Health Phys. 13, No. 6, 575-586 (June 1967).

Ferromagnetic iron alloys lacking a hyperfine field at the iron site, L. H. Bennett and L. J. Swartzendruber, Physics Letters 24A, No. 7, 359-360 (Mar. 27, 1967).

Future spectroscopy for late-type stars, C. E. Moore, Proc. Colloquium on Late-Type Stars, Trieste, Italy, June 13-17, 1966, pp. 15-24 (Stampato Presso, Trieste, Italy, 1967).

High purity powdered CsI as a high reflectance infrared diffuser, J. Geist, G. J. Kneissl, and V. R. Weidner, Appl. Opt. 6, No. 7, 1280-1281 (July 1967).

Internal friction in rutile containing $\mathrm{Ni}$ or Cr, J. B. Wachtman, Jr., S. Spinner, W. S. Brower, T. Fridinger, and R. W. Dickson, Phys. Rev. 148, No. 2, 811-816 (Aug. 12, 1966).

Report on international conference on spectroscopy, Bombay, 9-18 January 1967, C. E. Moore (Intern. Conf. Spectroscopy, Bombay, India, Jan. 9-18, 1967), Appl. Opt. 6, No. 5, 836 (May 1967).

Interpretation of the far infrared laser oscillation in ammonia, D. R. Lide, Jr., Physics Letters 24A, No. 11, 599-600 (May 1967).

Irradiation-induced color centers in magnesium fluoride, R. F. Blunt and M. I. Cohen, Phys. Rev. 153, No. 3, 1031-1038 (Jan. 15, 1967).

Lineshapes due to anisotropic interactions in magnetic resonance experiments, R. A. Forman and A. H. Kahn, J. Chem. Phys. 45, No. 12, 4586-4588 (Dec. 15, 1966).

Low-temperature heat capacity of $\mathrm{NdCl}_{3}$ and $\mathrm{PrCl}_{3}, \mathrm{~J}$. H. Colwell and B. W. Mangum, J. Appl. Phys. 38, No. 3, 1468-1469 (Mar. 1, 1967).

Mean lives of atomic levels excited by electron impulse, J. Z. Klose, Proc. Intern. Conf. Electronic Excitation of an Atomic Vapor-Application to Spectroscopy, Grenoble, France, May 23-26, 1966, pp. 191-192 (Centre Natl. de la Recherche Scientifique, Paris, France, 1967).

Microwave line shape and the inversion spectrum of $\mathrm{ND}_{3}$ and $\mathrm{ND}_{3}-$ argon mixtures, A. A. Maryott and S. J. Kryder, J. Chem. Phys. 46, No. 7, 2856-2857 (Apr. 1967).

Modulus of rupture of glass below room temperature, M. J. Kerper and T. G. Scuderi, Am. Ceramic Soc. Bull. 45, No. 9, 782-783 (Sept. 7, 1966).

Molecules in the sun, C. E. Moore-Sitterly, Proc. Symp. "Sun Spots" honoring Galileo, Florence, Italy, Sept. 9-12, 1964, Ed. G. Righini, pp. 181-185 (G. Barbera, Editore, Florence, Italy, 1966).

Multichannel photo-ionization of atomic systems, R. J. W. Henry and L. Lipsky, Phys. Rev. 153, No. 1, 51-56 (Jan. 1967).

Multichannel resonances in the inelastic scattering of electrons by helium, G. E. Chamberlain, Phys. Rev. 155, No. 1, 46-51 (Mar. 5,1967 ).

Newly measured and calculated wavelengths in the vacuum ultraviolet spectrum of neutral nitrogen, V. Kaufman and J. F. Ward, Appl. Opt. 6, No. 1, 43-46 (Jan. 1967).

Nuclear magnetic resonance of nitrogen-14 in potassium azide, R. A. Forman, J. Chem. Phys. 45, No. 4, 1118-1123 (Aug. 13, 1966).

Nuclear magnetic resonance of ${ }^{7} \mathrm{Li}$ and ${ }^{1} \mathrm{H}$ in solid lithium imide, lithium amide, and lithium nitride, P. J. Haigh, R. A. Forman, and R. C. Frisch, J. Chem. Phys. 45, No. 3, 812-816 (Aug. 1, 1966).

Nuclear-resonance spin-echo study of ${ }^{61} \mathrm{Ni}$ hyperfine fields in ferromagnetic Ni-Al, Ni-V, and Ni-Cr systems, R. L. Streever and G. A. Uriano, Phys. Rev. 149, No. 1, 295-301 (Sept. 9, 1966).

On the diffraction profiles of spectrograph slits of finite width, K. D. Mielenz, Optik 25, No. 3, 138-139 (May 17, 1967).

Optical properties of $\mathrm{SrTiO}_{3}$ under applied stress and electric field, R. C. Casella, Phys. Rev. 154, No. 3, 743-749 (Feb. 15, 1967).

Oscillatory photoconductivity and luminescence in $\mathrm{SrTiO}_{3}, \mathrm{~L} . \mathrm{H}$. Grabner, Proc. Cairo Solid State Conf., Cairo, Egypt, Sept. 3-8, 1966, Book Interactions of Radiation with Solids, Ed. A. Bishay, pp. 155-160 (Plenum Press, Inc., New York, N.Y., 1967).

Photographic and spectroscopic studies of exploding wires in a sealed vessel, E. C. Cassidy and K. K. Neumann (Proc. 7th Intern.
Cong. High-Speed Photography, Zurich, Switzerland, Sept. 12-18, 1965), Book, Kurzzeitphotographie, Ed. O. Helwich, pp. 178-185 (Verlag Dr. Othmar Helwich, Darmstadt, West Germany, 1967).

Piezo-optical effects in solids by sample rotation, A. Feldman, Physics Letters 23, No. 11, 627-628 (Dec. 12, 1966).

Radioactivity criteria for radiation processing of foods, H. W. Koch and E. H. Eisenhower, Book, Radiation Preservation of Foods, Advances in Chemistry Series 65 (American Chemical Society, Washington, D.C., 1967), chapt. 7, pp. 87-108.

Reactor physics in the resonance and thermal regions, D. T. Goldman, J. Franklin Inst. 283, No. 5, 437-438 (May 1967).

Reflective scattering from substrates and evaporated films in the far ultraviolet, R. G. Johnston, L. R. Canfield, and R. P. Madden, Appl. Opt. 6, 719 (Apr. 1967).

Resonances in the photo-ionization continuum of Ne I $(20-150 \mathrm{eV})$, K. Codling, R. P. Madden, and D. L. Ederer, Phys. Rev. 155, No. 1, 26-37 (Mar. 5, 1967).

Scattering of cold neutrons in ammonium carbonate, ammonium citrate, and ammonium acetate, V. Myers, J. Chem. Phys. 46, No. 10, 4034-4035 (May 1967).

Spectral distribution of scattered light in a simple fluid, R. D. Mountain, Rev. Mod. Phys. 38, No. 1, 205-214 (Jan. 1966). Spectroscope slit images in partially coherent light, K. D. Mielenz, J. Opt. Soc. Am. 57, No. 1, 66-74 (Jan. 1967).

Status of the National Standards for physical measurement, R. D. Huntoon, Science 150, No. 3693, 169-178 (Oct. 8, 1965).

Stretch scheme, a microscopic description of rotations in nuclei, M. Danos and V. Gillet, Phys. Rev. Letters 17, No. 13, 703-705 (Sept. 26, 1966).

Structure of the alkali hydroxides. I. Microwave spectrum of gaseous CsOH, D. R. Lide and R. L. Kuczkowski, J. Chem. Phys. 46, No. 12, 4768-4774 (June 1967).

$\mathrm{SU}(3)$ reaction inequalities at high energies, S. Meshkov and G. B. Yodh, Phys.Rev. Letters 18, No. 12, 474-481 (Mar. 1967).

The basis of our measurement system, R. D. Huntoon, Phys. Teacher 4, No. 3, 113-120 (Mar. 1966).

The elastic energies of non-regular hexagonal dislocation loops, R. DeWit and A. W. Ruff, Jr., Phil. Mag. 15, No. 137, 1065-1069 (May 1967).

The photonuclear effect in heavy deformed nuclei, H. Arenhovel, W. Greiner and M. Danos, Phys. Rev. 157, No. 4, 1109-1125 (May 1967).

The standardization of cobalt-57, S. B. Garfinkel and J. N. R. Hutchinson, Intern. J. Appl. Radiation Isotopes 17, No. 10, 587-593 (Oct. 1966).

Temperature dependence of the high-frequency moduli of vitreous $\mathrm{B}_{2} \mathrm{O}_{3}$, W. Capps, P. B. Macedo, B. O'Meara, and T. A. Litovitz, J. Chem. Phys. 45, No. 9, 3431-3438 (Nov. 1, 1966).

Transactions of the triple commission for spectroscopy, Subcommittee D-Atomic Spectra, C. E. Moore, J. Opt. Soc. Am. 55, No. 6, 745 (1965).

Treatment of nuclear reactions above the two-particle threshold, M. Danos and W. Greiner, Z. Phys. 202, 125 (1967).

Triple-filament method for solid-sample lead isotope analysis, E. J. Catanzaro, J. Geophys. Res. 72, No. 4, 1325-1327 (Feb. 15, 1967). Vacuum ultraviolet wavelength standards and improved energy levels in the first spectrum of silicon, L. J. Radziemski, Jr., K. L. Andrew, V. Kaufman, and U. Litzen, J. Opt. Soc. Am. 5 7, No. 3 , 336-340 (Mar. 1967).

W spin for any spin, H. Harari, D. Horn, M. Kugler, H. J. Lipkin, and S. Meshkov, Phys. Rev. 146, No. 4, 1052-1057 (June 24, 1966).

Adsorption correction in the Weissenberg methods, A. Santoro and M. Zocchi, Acta Cryst. 22, 918-919 (June 1967).

A determination of trace amounts of iron and cobalt in the same sample by substoichiometric radioisotopic dilution analysis, A. R. Landgrebe, L. McClendon, and J. R. DeVoe (Proc. 1964 Winter Meeting American Nuclear Society, San Francisco, Calif., Nov. 30-Dec. 3, 1964), Trans. Am. Nucl. Soc. 7, No. 2, 337-338 (Nov. 1964).

Application of radiometric techniques to quantitative paper chromatography of iron, copper, manganese, and cobalt, A. R. Landgrebe, T. E. Gills, and J. R. DeVoe, Anal. Chem. 38, No. 9, 1265-1266 (Aug. 1966).

A study of the heat of formation of oxygen difluoride, R. C. King and G. T. Armstrong, Proc. Fifth Meeting ICRPG, Working Group on Thermochemistry 1, CPIA Publ. 146, May 1967.

Crystal nucleation in polyethylene: the droplet experiment, F. 
Gornick, G. S. Ross, and L. J. Frolen, J. Polymer Sci. 18, Part C, 79-91 (1967).

Effects of temperature and of ultraviolet radiation on pyrene adsorbed on garden soil, A. J. Fatiadi, Environ. Sci. Technol. 1, No. 7, 570-572 (July 1967).

Electrolysis of nonaqueous systems, A. Brenner, Book, Advances in Electrochemistry and Electrochemical Engineering, Ed. C. W Tobias, V, 205-248 (John Wiley \& Sons, Inc., New York, N.Y., 1967).

Electron probe microanalysis, K. F. J. Heinrich, Book, Experimental Methods of Materials Research. Advances in Materials Research 1, 145-162 (John Wiley \& Sons, Inc., New York, N.Y. 1967).

Extraction-spectrophotometric determination of antimony as a ternary complex, R. W. Burke and O. Menis, Anal. Chem. 38, p. 1719 (Nov. 1966).

Free rotation of methyl groups in dimethyltin difluoride, J. J. Rush and W. C. Hamilton, Inorg. Chem. 5, No. 12, 2238-2239 (Dec. 1966).

Gas phase photolysis and radiolysis of methane. Formation of hydrogen and ethylene, R. Gorden, Jr. and P. Ausloos, J. Chem. Phys. 46, No. 12, 4823-4833 (June 15, 1967).

Laser probe excitation in spectrochemical analysis. I. Characteristics of the source, S. D. Rasberry, B. F. Scribner, and M. Margoshes, Appl. Opt. 6, No. 1, 81-86 (Jan. 1967).

Laser probe excitation in spectrochemical analysis. II. Investigation of quantitative aspects, S. D. Rasberry, B. F. Scribner, and M. Margoshes, Appl. Opt. 6, No. 1, 87-93 (Jan. 1967).

$p \mathrm{H}$ determination, R. G. Bates, Encyclopedia of Industrial Chemical Analysis 3, 146-161 (John Wiley and Sons, Inc., New York, N.Y. 1966).

Rate constants and the mechanism for the transfer of triplet excitation energy, R. A. Keller and L. J. Dolby, J. Am. Chem. Soc. 89, 2768-2770 (May 1967).

Study of low-frequency motions in several ferroelectric salts by the inelastic scattering of cold neutrons, J. J. Rush and T. I. Taylor, Proc. 3d Symp. Inelastic Scattering of Neutrons, Bombay, India, 1965, II, 333 (1965).

Surface studies of natural and synthetic bone mineral teeth, W. V. Loebenstein (Proc. 2d Workshop, Adhesive Restorative Dental Materials, University of Virginia, Charlottesville, Va., Dec. 8-9, 1965), Book, Adhesive Restorative Dental Materials, Chapt. IV. Surface Measurements-Synthesis and Evaluation of Dental Adhesives, pp. 213-223 (Dept. of Health and Education and Welfare, W ashington, D.C. 1966).

Testing scouring powder abrasion, W. C. Wolfe, Detergent Age 2, No. 10, 22 (Mar. 1966).

The estimation of molecular weights of vinyl acetate copolymers in latex paints, H. W. Berger, J. Paint Technol. 39, No. 508, 310-315 (May 1967).

The National Standard Reference Data System program in atomic and molecular properties, S. A. Rossmassler (Proc. Symp. Compilations of Data on Chemical and Physical Properties of Substances, 152d National Meeting, Am. Chem. Soc., New York, N.Y. Sept. 12, 1966), J. Chem. Doc. 7, No. 1, 15-18 (Feb. 1967).

The radiation-induced copolymerization of tetrafluoroethylene and 3,3,3-trifluoropropene at high pressure, D. W. Brown and L. A. Wall (Proc. Symp. Compilations of Data on Chemical and Physical Properties of Substances, 152d National Meeting, Polymer Preprint 7, No. 2, 1116-1132 (Sept. 1966).

Volume change on formation of native collagen aggregate, J. Cassel and R. G. Christensen, Biopolymers 5, 431-437 (1967).

A dual frequency VLF timing system, L. Fey and C. H. Looney, IEEE Trans. Instr. Meas. IM-15, No. 4, 190-195 (Dec. 1966).

An analysis of low information rate time control unit, L. Fey, J. A Barnes, and D. W. Allan, Proc. 20th Annual Symp. Frequency Control, Atlantic City, N.J., Apr. 19-21, 1966, pp. 629-635 (1966).

An equation for the local thermal emissivity at the vertex of a diffuse conical or V-groove cavity, F. J. Kelly, Appl. Opt. 5, 925-927 (June 1966).

A precision current comparator, C. M. Allred and R. A. Lawton (Proc. Annual ISA Conf., New York, N.Y., Oct. 1966), ISA Preprint No. 12, 8-2-66 (Oct. 1966).

Calorimetric measurement of pulsed laser output energy, D. A. Jennings, IEEE Trans. Instr. Meas. IM-15, No. 4, 161-164 (Dec. 1966).

Conference on burns and flame retardant fabrics, December 1966, New York, N.Y., A. F. Robertson, Fire Res. Abst. Rev. 9, No. 2, 119-122 (1967).
Doors as barriers to fire and smoke, H. Shoub and D. Gross, Proc. Symp. Fire Testing, Lancaster, Pa., June 24-25, 1965, pp. I-1I-10 (Armstrong Cork Co., Lancaster, Pa., 1965).

Field strength above $1 \mathrm{GHz}$ : Measurement procedures for standard antennas, R. R. Bowman, Proc. IEEE 55, No. 6, 981-990 (June 1967).

Impedance measurements and standards for uniconductor waveguide, R. W. Beatty, Proc. IEEE 55, No. 6, 933-941 (June 1967). Impedance measurements in coaxial waveguide systems, R. L. Jesch and R. M. Jickling, Proc. IEEE 55, No. 6, 912-923 (June 1967). International comparison of high frequency electromagnetic quantities, M. C. Selby, Proc. IEEE 55, No. 6, 745-747 (June 1967).

Long-time effects of humidity change on the dielectric properties of certain polymers, A. H. Scott and W. P. Harris (Proc. 1962 Annual Report Conf. Electrical Insulation. Hershey, Pa., Oct. 15-17, 1962), Natl. Acad. Sci.-Natl. Res. Council Publ. 1080, pp. 41-44 (1963).

Lumped parameter impedance measurements, L. E. Huntley and R. N. Jones, Proc. IEEE 55, No. 6, 900-911 (June 1967).

Measurement of RF peak pulse power, P. A. Hudson, Proc. IEEE 55, No. 6, 851-855 (June 1967).

Micrometer U-tube manometers for medium vacuum measurements, A. M. Thomas and J. L. Cross, J. Vacuum Sci. Technol. 4, No. 1, 1-5 (Jan.-Feb. 1967)

NBS Field-strength standards and measurements $(30 \mathrm{~Hz}$ to 1000 MHz), F. M. Greene, Proc. IEEE 55, No. 6, 970-981 (June 1967).

Peak pulse voltage measurement (baseband pulses), A. R. Ondrejka, Proc. IEEE 55, No. 6, 882-885 (June 1967).

Physical and performance properties of leather, J. R. Kanagy, Book, The Chemistry and Technology of Leather 4, chapt. 64, 369-416 (Reinhold Publ. Corp., New York, N.Y., 1965).

Precision coaxial connectors in lumped parameter immittance measurements, R. N. Jones and L. E. Huntley, IEEE Trans. Instr. Meas. IM-15, No. 4, 375-380 (Dec. 1966).

Progress in the development of a thermal-shock-resistance factor for bituminous built-up roofing, W. C. Cullen and T. H. Boone, ASTM Spec. Tech. Publ. 409, 151-161 (Apr. 1967).

Radio frequency power measurements, A. Y. Rumfelt and L. B. Elwell, Proc. IEEE 55, No. 6, 837-850 (June 1967).

RF attenuation, D. H. Russell and W. Larson, Proc. IEEE 55, No. 6, 942-959 (June 1967).

RF measurements of the speed of light, R. C. Baird, Proc. IEEE 55, No. 6, 1032-1039 (June 1967).

Sampling of leather for physical and chemical examination, J. Mandel and J. R. Kanagy, Book, The Chemistry and Technology of Leather 4, chapt. 59, 223-242 (Reinhold Publ. Corp., New York, N.Y. 1965).

Standards for galvanomagnetic devices, S. Rubin (Proc. Committee on Hall Effect Applications, Cambridge, Mass., Nov. 8-9, 1965), Book, Solid State Electronics 9, No. 65, 559-566 (Pergamon Press Inc., New York, N.Y., 1966).

Some accuracy limiting effects in an atomic beam frequency standard, R. J. Harrach, Proc. 20th Annual Symp. Frequency Control, Atlantic City, N.J., Apr. 19-21, 1966, pp. 424-435 (1966).

Superconducting devices, T. M. Flynn and K. D. Timmerhaus (Proc. Intern. Inst. Refrigeration Meeting of Comm. 1, Boulder, Colo., June 15-17, 1966), Book, Liquid Helium Technology, Bull. IIR Annexè 1966-5, pp. 459-490 (Paris, France, 1967).

Technological innovation: its environment and management, D. V De Simone, U.S. Department of Commerce C1.2:T22 (Supt. Docs., Govt. Printing Office, Washington, D.C., Jan. 1967).

The innovator, D. V. De Simone, Engineer 8, No. 1, 8-9 (Jan.-Feb. 1967).

The Measurement of baseband pulse risetimes of less than $10^{-9}$ seconds, N. S. Nahman, Proc. IEEE 55, No. 6, 855-864 (June 1967).

The measurement of current at radio frequencies, W. W. Scott, Jr and N. V. Frederick, Proc. IEEE 55, No. 6, 886-891 (June 1967).

The role of the CCRL, J. R. Dise, Construct. Specifier 20, 54-60 (June 1967)

Transistorized UHF marginal oscillator and its application for the measurement of the magnetic flux density, S. Rubin, Proc. IEEE Letter 53, No. 9, 1249-1250 (Sept. 1965).

UHF and microwave phase shift measurements, D. A. Ellerbruch, Proc. IEEE 55, No. 6, 960-969 (June 1967).

Voltage measurement at high and microwave frequencies in coaxial systems, M. C. Selby, Proc. IEEE 55, No. 6, 877-882 (June 1967). 
Computer languages and their use, S. N. Alexander, Am. Mgmt. Assoc. Mgmt. Bull. 79, 8-12 (1966).

The mathematical representation of physical entities, C. H. Page, IEEE Trans. Educ. E-10, No. 2, 70-74 (June 1967).

Calibration of germanium thermometers from 2 to $20^{\circ} \mathrm{K}$, G. Cataland and H. H. Plumb (Proc. Intern. Inst. Refrigeration Meeting of Comm. 1, Boulder, Colo., 1966, Annexe 1966-5), Suppl. Bull. Inst. Intern. Froid, pp. 153-163 (Louvain, Belgium, 1966).

Noise standards, measurements, and receiver noise definitions, C. K. S. Miller, W. C. Daywitt, and M. G. Arthur, Proc. IEEE 55, No. 6, 865-877 (June 1967).

On the problems of measuring transient temperature in cryogenic fluids, C. E. Miller and T. M. Flynn, ISA Trans. 6, No. 2, 133-138 (Apr.-June 1967).

Progress report for O.S.A. committee on uniform color scales, D. B. Judd, Die Farbe 14, 287-295 (1965).

The use of semiconductors for the study of boiling heat transfer to low temperature liquids, G. G. Harman and L. H. Gordy, Cryogenics 7, 89-92 (Apr. 1, 1967).

Almost "head-on" collisions in the scattering of fast argon atoms by hydrogen isotopes, J. E. Jordan and I. Amdur, J. Chem. Phys. 46, No. 10, 4145-4146 (May 1967).

Anomalous specific heat and viscosity of binary van der Waals mixtures, J. M. Deutch and R. Zwanzig, J. Chem. Phys. 46, No. 5, 1612-1620 (Mar. 1, 1967).

Detachment of electrons from $\mathrm{H}^{-}$by electron impact, G. C. Tisone and L. M. Branscomb, Phys. Rev. Letters 17, No. 5, 236-238 (Aug. 1, 1966).

Diffusion and the Kirkendall shift in binary alloys, J. R. Manning, Acta. Met. 15, 817-826 (May 1967).

Digital computers, E. W. Cannon, Book, Encyclopedia of Physics, Ed. R. M. Besancon, pp. 124-125 (Reinhold Publ. Corp., New York, N.Y., 1966).

Effect on chromatic aberration on the resolving power of photographic objectives, F. E. Washer, J. Opt. Soc. Am. 57, No. 5, 625-629 (May 1967).

Electron impact dissociation of $\mathrm{H}_{2}^{+}$, G. H. Dunn and B. Van Zyl, Phys. Rev. 154, No. 1, 40-51 (Feb. 1967).

Exponential operators and parameter differentiation in quantum physics, R. M. Wilcox, J. Math. Phys. 8, No. 4, 962-982 (Apr. 1967).

Energetic ions from $\mathrm{N}_{2}$ produced by electron impact, L. J. Kieffer and R. J. Van Brunt, J. Chem. Phys. 46, No. 7, 2728-2734 (Apr. 1967).

Experimental transition probabilities for the Ar I $4 s-4 p$ array, J. B. Shumaker, Jr. and C. H. Popenoe, J. Opt. Soc. Am. 57, No. 1, 8-10 (Jan. 1967).

Formal theory of nonlinear response, R. L. Peterson, Rev. Mod. Phys. 39, No. 1, 69-77 (Jan. 1967).

$g_{I} / g_{J}$ ratios in $\mathrm{Rb}^{87}$ and $\mathrm{Rb}^{85}$, L. C. Balling, Bull. Am. Phys. Soc. 12, Series II, No. 4, 508 (Apr. 1967).

Hamilton's mixed and angle characteristic functions and diffraction aberration theory, A. B. Shafer, J. Opt. Soc. Am. 57, No. 5 , 630-639 (May 1967)

Lectures on critical phenomena, M. S. Green (Proc. Summer School of Theoretical Physics, Cargese, Corsica, Summer 1964), Book, Cargese Lectures in Theoretical Physics-Statistical Mechanics, Ed. B. Jancovici, pp. 59-88 (Gordon and Breach Publ., New York, N.Y., 1964).

Light scattering from time-dependent molecular orientations at raman frequencies in liquids, M. McClintock, D. A. Jennings, and M. Mizushima, Bull. Am. Phys. Soc. 12, Series II, No. 5, 711 (May 1967).

Measurements in a turbulent boundary layer maintained in a nearly separating condition, W. G. Spangenberg, W. R. Rowland, and N. E. Mease (Proc. Symp. Fluid Mechanics of Internal Flow, General Motors Research Labs., Warren, Mich., 1965), Book, Fluid Mechanics of Internal Flow, Ed. G. Sovarn, pp. 110-151 (Elsevier Publ. Co., Amsterdam, The Netherlands, 1967).

NBS to dedicate Gaithersburg facility, W. K. Wilson, J. Wash. Acad. Sci. 56, No. 7, 165-167 (Oct. 1966).
Neutron cross section evaluations-past, present, and future, K. Parker, D. T. Goldman, and L. Wallin (Proc. Intern. Atomic Energy Agency Conf. Reactors, Vienna, Austria, 1966), Book, Nuclear Data for Reactors II, 293 (1967).

NBSR converter tube, C. F. Kupiec and C. O. Muehlhause, Trans. Am. Nucl. Soc. 9, No. 2, 582-583 (Nov. 1966).

Observation of two intrinsic nuclear relaxation rates in antiferromagnetic $\mathrm{KMnF}_{3}$, R. J. Mahler, A. C. Daniel, and P. T. Parrish, Phys. Rev. Letters 19, No. 2, 85-87 (July 10, 1967).

Photographic standardization and research at the National Bureau of Standards, C. S. McCamy, Appl. Opt. 6, No. 1, 27-30 (Jan. 1967).

Radiation-field-dependent frequency shifts of atomic beam resonances, R. J. Harrach, J. Appl. Phys. 38, No. 4, 1808-1819 (Mar. 15, 1967).

Report on International Conference on Crystal Growth (ICCG), R. L. Parker (Proc. Intern. Conf. Crystal Growth, Boston, Mass., Dec. 1966), Phys. Today 19, No. 12, 109-111 (Dec. 1966).

Scaling-law equation of state for gases in the critical region, M. S. Green, M. Vincentini-Missoni, and J. M. H. L. Sengers, Phys. Rev. Letters 18, No. 25, 1113-1117 (June 19, 1967).

Short-range order in the Weiss molecular field approximation, R. L. Peterson, Bull. Am. Phys. Soc. 12, Series II, No. 4, 502 (Apr. 1967).

Shubnikov-de Hass effect in $\mathrm{SrTiO}_{3}, \mathrm{H}$. P. R. Frederiske, W. R. Hosler, and W. R. Thurber, Phys. Rev. 158, No. 3, 775-778 (June 15, 1967).

Some characteristic of commonly used time scales, G. E. Hudson, Proc. IEEE 55, No. 6, 815-821 (June 1967).

The calculation of nuclear cross-sections by the optical model, D. T. Goldman (Proc. Intern. Atomic Energy Agency Conf. Nuclear Data for Reactors, Vienna, Austria, 1966), Book, Nuclear Data for Reactors I, 339-364 (1967).

The effect of other metallic ions on the electrocrystallization of silver from nitrate solutions, J. P. Young, Plating, pp. 1-4 (Mar 1967).

The effects of rotor deceleration on equilibrium sedimentation experiments, I. H. Billick, M. Dishon, M. Schulz, G. H. Weiss, and D. A. Yphantis, Proc. Natl. Acad. Sci. 56, No. 2, 399 (Aug. 1966).

The momentum autocorrelation function in a Bernoulli chain, R. J. Rubin and P. Ullersma, J. Math. Phys. 7, No. 10, 1877-1885 (Oct. 1966).

The production and use of monoenergetic electron beams, J. A. Simpson, Proc. 8th Annual Electron and Laser Beam Symp., University of Michigan, Ann Arbor, Mich., Apr. 6-8, 1966, pp. 437-447 (1966).

Two-mirror systems with spherical reflecting surfaces, O. N. Stavroudis, J. Opt. Soc. Am. 57, No. 6, 741-748 (June 1967).

$\mathrm{X}$-ray diffraction measurement of stacking faults in alpha silver-tin alloys, C. J. Newton and A. W. Ruff, Jr., J. Appl. Phys. 37, No. 10, 3860-3868 (Sept. 1966).

Distribution of standard frequency and time signals, A. H. Morgan, Proc. IEEE 55, No. 6, 827-836 (June 1967).

Measurement of RF properties of materials - A survey, H. E. Bussey, Proc. IEEE 55, No. 6, pp. 1046-1053 (June 1967).

Of time and frequency, D. H. Andrews, Book, How to Listen to the World, pp. 3-7 (World Publ., Hellerup, Denmark, Jan. 1967). Preliminary results of some new measurements of phase velocity at VLF, G. Kamas, A. H. Morgan, and J. L. Jespersen, Radio Sci. 1, No. 12, 1409-1410 (Dec. 1966).

*Publications for which a price is indicated are available by purchase from the Superintendent of Documents, U.S. Government Printing Office, Washington, D.C. 20402 (foreign postage, onefourth additional). The NBS nonperiodical series are also available from the Clearinghouse for Federal Scientific and Technical Information, Springfield, Va. 22151. Reprints from outside journals and the NBS Journal of Research may often be obtained directly from the authors. 